\title{
PERBANDINGAN UJI EFEKTIVITAS INFUSA REBUSAN AKAR BAYAM DURI \\ (Amaranthus spinosus L) DAN UJI EFEKTIVITAS INFUSA AKAR KECAPI (Sandoricum koetjape) TERHADAP MENCIT JANTAN (MUS MUCSULUS) SEBAGAI OBAT ANTI DIARE
}

\author{
**)Dian Furqani Hamdan \\ **)STIKES Bhakti Pertiwi Luwu Raya Palopo \\ **)Program Studi D-III Farmasi STIKES Bhakti Pertiwi Luwu Raya Palopo
}

\begin{abstract}
ABSTRAK
Telah dilakukan penelitian mengenai Perbandingan Uji Efektivitas Infusa Rebusan Akar Bayam Duri (Amaranthus spinosus L) dan Uji Efektivitas Infusa Akar Kecapi (Sandoricum koetjape) Terhadap Mencit Jantan (Mus mucsulus Sebagai Obat Anti Diare. Penggunaan obat tradisional dengan ekstrak tumbuhan sebagai obat penanganan pertama terhadap penyakit diare telah lama digunakan oleh leluhur kita, dengan kemajuan teknologi, ilmu semakin berkembang dan manusia mulai memikirkan dapak jangka panjang dari mengkonsumsi obat, sehingga penelitian ini bertujuan membuktikan secara ilmiah penggunaan obat tradisonal seperti akar bayam duri dan akar kecapi terbukti efektif sebagai obat anti diare yang dapat digunakan masayarakat bila sewaktu-waktu mengalami penyakit diare, dimana alat dan bahannya sangat murah dan mudah ditemukan dalam kehidupan kita sehari-hari. Penelitian ini bertujuan untuk tingkat efektifitas dari keua bahan ini ternyata tidak terlalu menampakkan perbedaan yang signifikan.
\end{abstract}

Kata Kunci : Anti diare, Rebusan Akar Bayam Duri, Infusa akar kecapi, Mencit Jantan

\section{PENDAHULUAN}

\section{A. Latar Belakang}

Pengetahuan tentang tumbuhan berkhasiat obat berdasarkan pada pengalaman dan keterampilan yang secara turun-temurun telah diwariskan dari satu generasi kegenerasi berikutnya, penggunaan bahan alam sebagai obat tradisional dilakukan nenek moyang kita sejak berabad-abad yang lalu (Sari, 2006).

Tanaman bayam di golongkan ke dalam keluarga Amaranthaceae, marga Amaranthus, Sebagai keluarga amaranthaceae. Bayam termasuk tanaman gulma yang tumbuh liar. Namun, karna perkembanganya manusia memanfaatkan tanaman bayam sebagai tanaman budidaya yang mengandung gizi tinggi (Priyanto,2009).

Rebusan akar bayam duri $30 \%$ per oral dapat meningkatkan kadar besi serum, haemoglobin, dan hematokrit, mencit yang dibuat diare secara nyata. Peningkatan tersebut tidak berbeda jika di bandingkan dengan kelompok mencit yang diberi sulfas ferosus, sebagai pembanding, digunakan air suling (Ernawati Santoso, Fakultas Farmasi, WIDMAN,1986).

Tumbuhan sebagai obat tradisional,biasanya digunakan secara tunggal (satu jenis tumbuhan) atau majemuk (campuran dari beberapa jenis tumbuhan). Bagian tumbuhan yang umum digunakan sebagai obat tradisional adalah daun, bunga, kulit batang, atau akarnya. Penggunaannya ada secara langsung dalam keadaan masih segar, ada pula yang diseduh atau direbus (Bahasoan,dkk. 2007).
Daun kecapi berkhasiat sebagai obat penurun demam dan peluruh keringat (Harborne, 2009), juga berkhasiat sebagai obat batuk, obat mulas dan keputihan (Jazanul, 2009). Bagian tumbuhan lainnya juga sangat bermanfaat, kulit batangnya untuk pengobatan cacing gelang dan kurap, akarnya untuk obat kembung, diare, sakit pinggang serta untuk penguat tubuh wanita setelah melahirkan (Juffrie, 2010).

\section{B. Rumusan Masalah}

Rumusan masalah dalam penelitian ini adalah untuk membandingkan efek dari ekstaksi akar bayam duri dengan akar kecapi sebagainobat anti diare dengan menggunakan mencit jantan sebagai hewan percobaan

\section{Tujuan Penelitian}

Penelitian ini bertujuan untuk mengetahui tingkat perbedaan efek obat anti diare dari kedua akar tumbuhan (akar bayam duri dan akar kecapi) yang telah akrab dikehidupan masyarakat seharihari

\section{Manfaat Penelitian}

Diharapkan penelitian ini sebagai sumber informasi di masyarakat tentang manfaat akar tumbuhan sebagai obat anti diare bila sewaktu ada keluarga yang mengalami diare dan tidak terdapat obat diare sehingga ekstraksi akar tumbuhan dapat dijadikan obat alternatif pertolongan pertama. 


\section{METODE PENELITIAN}

\section{A. Jenis Penelitian}

Penelitian ini termasuk jenis penelitian eksperimental laboratorium pada dua tumbuhan sebagai efek anti diare rebusan Akar Bayam Duri (Amaranthus spinosus L) dengan Konsetrasi $10 \% \mathrm{~b} / \mathrm{v}, 30 \% \mathrm{~b} / \mathrm{v}$, dan $40 \% \mathrm{~b} / \mathrm{v}$. Serta infusa akar kecapi (Sandoricum koetjape) dengan konsentrasi $15 \% \mathrm{~b} / \mathrm{v}, 30 \% \mathrm{~b} / \mathrm{v}$, dan 45\%b/v. Terhadap hewan uji mencit jantan (Mus musculus).

\section{B. Waktu dan Tempat Penelitian}

Penelitian ini dilaksanakan pada bulan Maret 2019, di laboratorium Farmasi STIKES Bhakti Pertiwi Luwu Raya Palopo.

\section{Sampel Penelitian}

Penelitian ini menggunakan dua kelompok dengan sampel sebanyak 30 ekor mencit kelompok pertama diberikan perlakuan menggunakan uji efektifitas rebusan akar bayam duri (Amaranthus spinosus) sebanyak 15 ekor mencit jantan, yang di bagi atas (5) kelompok dan tiap kelompok terdiri dari 3 ekor mencit jantan, begitu pula untuk rebusan akar kecapi (Sandoricum koetjape).

Mencit Jantan 30 Ekor, dilakukan pemeliharaan, ditumbang kemudian dipuasakan setelah itu di induksi oleum ricini $0,5 \mathrm{ml}$ kemudian mencit mengalami diare. Akar bayam duri (Amaranthus spinosus) dibersihkan kemudian dirajang-rajang dan ditimbang selanjutnya dilakukan ekstraksi. Akar kecapi (Sandoricum koetjape) dibersihkan lalu dirajang-rajang kemudian ditimbang, selanjutnya dibuat infus Akar kecapi.

\section{Alat dan Bahan Penelitian}

Alat yang di gunakan dalam penelitian ini adalah spoit injeksi (intra peritoral) dan spoit injeksi ujung tumpul (peroral), panci infusa, kompor, lumpang dan stamper, gelas ukur, kain flannel, spidol, batang pengaduk, corong, erlenmeyer, gelas ukur (pyrex), kain kasa, kanula, kandang hewan uji, labu ukur, stopwatch, timbangan gram kasar (acis), timbangan hewan uji (barkel).

Bahan yang di gunakan dalam penelitian ini adalah aquadest, akar bayam duri (Amaranthus spinosus), akar kecapi (Sandoricum koetjape), oleum ricini, tablet loperamid (generik), dan tissue.

\section{E. Metode Kerja}

a. Penyiapan Bahan Baku

1. Pengambilan Sampel

Sampel berupa akar kecapi (Sandoricum Koetjape) dan akar bayam duri (Amaranthus spinosus) yang diperoleh dari Desa Lamasi Pantai Kecamatan Walenrang Kabupaten Luwu Provinsi Selatan
2. Pengolahan sampel

Sampel berupa akar kecapi (Sandoricum koetjape) dan akar bayam duri (Amaranthus spinosus) yang diperoleh dengan cara mengambil akar kecapi yang masih segar dari pohon, di kumpulkan kemudian dibersihkan dari kotoran yang menempel di akar, kemudian di potong-potong kecil lalu timbang sesuai dengan konsentrasi yang di inginkan.

3. Pembuatan Infusa Akar Kecapi (Sandoricum koetjape)

Pembuatan infusa akar kecapi dengan konsentrasi $15 \%$ dilakukan dengan cara ditimbang 15 gram akar kecapi segar, dimasukkan kedalam panci infusa dibasahi dengan air suling 2 kali berat simplisia diaduk sehingga semua simplisia menjadi basah, dibiarkan 10 menit kemudian ditambahkan air suling sebanyak $100 \mathrm{ml}$ dalam panci infusa. Dipanaskan selama 15 menit, dihitung mulai pada saat didalam panci infusa mencapai $90^{\circ} \mathrm{C}$ sambil sekali-kali diaduk, angkat kemudian disaring lalu dicukupkan volumenya sampai $100 \mathrm{ml}$. Infusa disaring selagi panas dimaksudkan agar zat aktif dalam tanaman benar-benar tersaring dengan sempurna. Hal yang sama dilakukan untuk membuat infusa konsentrasi 30\% (30 gram akar kecapi), dan 45\% (45 gram akar kecapi).

4. Pembuatan Infusa Akar bayam duri (Amaranthus spinosus)

Pembuatan infusa akar bayam duri dengan konsentrasi $15 \%$ dilakukan dengan cara ditimbang 15 gram akar kecapi segar,dimasukkan kedalam panci infusa dibasahi dengan air suling 2 kali berat simplisia diaduk sehingga semua simplisia menjadi basah, dibiarkan 10 menit kemudian ditambahkan air suling sebanyak $100 \mathrm{ml}$ dalam panci infusa. Dipanaskan selama 15 menit, dihitung mulai pada saat didalam panci infusa mencapai $90^{\circ} \mathrm{C}$ sambil sekali-kali diaduk, angkat kemudian disaring lalu dicukupkan volumenya sampai $100 \mathrm{ml}$. Infusa disaring selagi panas dimaksudkan agar zat aktif dalam tanaman benar-benar tersaring dengan sempurna. Hal yang sama dilakukan untuk membuat infusa konsentrasi 30\% (30 gram akar bayam duri), dan 45\% (45 gram akar bayam duri).

5. Pembuatan suspensi loperamid Suspensi loperamid dibuat dengan menimbang 20 tablet loperamid dan 
dihitung bobot rata-rata 1 tablet, ambil 2 tablet masukkan kedalam lumpang kemudian di gerus hingga menjadi serbuk. Ditambahkan sedikit demi sedikit suspensi Na.CMC 1\% b/v sambil di gerus hingga homogen, sediaan yang homogen di masukkan kedalam labu ukur $100 \mathrm{ml}$, kemudian dicukupkan volumenya dengan suspensi Na.CMC $1 \% \mathrm{~b} / \mathrm{v}$ sampai batas tanda.

b. Pemilihan dan penyediaan hewan uji

1. Pemilihan hewan uji

2. Hewan uji yang digunakan adalah mencit (Mus musculus) jantan yang sehat, gerakan lincah, bulunya bersih, dewasa albino galur lokal, penurunan berat badan tidak boleh lebih dari 5-10\% dari berat badan semula, berumur 3-4 bulan dengan berat badan 15-25 gram.

3. Penyiapan hewan uji

4. Disiapkan 15 ekor mencit jantan, dimana hewan uji tersebut di bagi dalam 5 kelompok di setiap kelompok terdiri 3 hewan uji untuk uji infusa akar bayam duri. Dan 15 ekor mencit jantan, dimana hewan uji tersebut di bagi dalam 5 kelompok di setiap kelompok terdiri 3 hewan uji untuk uji infusa akar kecapi.

c. Perlakuan terhadap hewan uji

1. Sebelum perlakuan mencit dipuasakan selama 3-4 jam, kemudian di timbang.

2. Setelah 10 menit perlakuan, mencit di induksikan dengan oleum ricini 0,5 $\mathrm{ml} /$ setiap ekor mencit secara oral untuk membuat mencit diare.

3. Kemudian masing-masing kelompok di berikan perlakuan dengan konsentrasi sebagai berikut :

1. Kelompok I: Infusa akar kecapi/akar bayam duri dengan konsentrasi $15 \% \mathrm{~b} / \mathrm{v}$ dengan dosis $0,52 \mathrm{ml} / 20 \mathrm{BB}$ mencit

2. Kelompok II: Infusa akar kecapi/akar bayam duri dengan konsentrasi $30 \%$ b/v dengan dosis 0,52/20 BB mencit.

3. Kelompok III: Infusa akar kecapi/akar bayam duri dengan konsentrasi $45 \%$ b/v dengan dosis 0,52 BB mencit.

4. Kelompok IV: Suspensi loperamid sebagai kontrol positif

5. Kelompok V: Aquqdest 1\% sebagai kontrol negatif.

d. Pengamatan

Pengamatan dilakukan dengan parameter konsistensi tinja, dan frekuensi diare, kemudian dicatat komulatif frekuensi diare yang timbul dalam selang waktu 30 menit selama 3 jam. e. Pengumpulan dan Analisis Data

Data dikumpulkan dari hasil pengamatan frekuensi defekasi dan konsistensi tinja yang timbul selama 3 jam setelah pemberian Infusa akar buah kecapi/akar bayam duri $15 \%$ b/v, $30 \% \mathrm{~b} / \mathrm{v} 45 \% \mathrm{~b} / \mathrm{v}$, setelah pemberian suspensi loperamid dan setelah pemberian Aquadest $1 \%$. Data yang diperoleh dianalisis secara statistic dengan menggunakan metode Anova, Rancangan acak lengkap (RAL)

\section{HASIL DAN PEMBAHASAN}

\section{A. Hasil Penelitian}

Perbandingan uji efek anti diare rebusan Akar Bayam Duri (amaranthus spinosus L) dan infusa akar kecapi (Sanouricum koetjape) terhadap mencit jantan menunjukan hasil sebagai berikut :

Tabel I. Jumlah frekuensi diare dan konsistensi tinja setelah pemberian rebusan akar bayam duri (Amaranthus spinosus L)

Jumlah Frekuensi Tinja Mencit Selama 4 Jam/30 Menit

\begin{tabular}{ccccccc} 
& \multicolumn{6}{c}{ Jumlah Frekuensi Tinja Mencit Selama 4 Jam/30 Menit } \\
\cline { 2 - 6 } Replikasi & $\begin{array}{c}\text { Aquadest } \\
\text { mencit }\end{array}$ & \multicolumn{2}{c}{ Infusa Akar Bayam Duri } & $\begin{array}{c}\text { Loperamid } \\
(+)\end{array}$ & Jumlah \\
\cline { 2 - 6 } & $(\mathbf{K l p 1 )}$ & $\mathbf{( K l p 2 )}$ & $\mathbf{( K l p 3 )}$ & $\mathbf{( K l p 4 )}$ & $\mathbf{( K l p 5 )}$ & \\
\hline 1 & 32 & 10 & 12 & 9 & 2 & 65 \\
\hline 2 & 28 & 13 & 12 & 6 & 3 & 62 \\
\hline 3 & 30 & 5 & 6 & 8 & 2 & 51 \\
\hline Jumlah & 90 & 28 & 30 & 23 & 7 & 178 \\
\hline Rara-rata & 15,6 & 6,6 & 11,3 & 5,6 & 2,7 & - \\
\hline
\end{tabular}

Sumber : Data Primer 2019

Tabel II. Jumlah Frekuensi rata-rata Tinja Mencit Pada Pemberian infusa akar kecapi (Sanouricum koetjape) terhadap mencit jantan

Jumlah Frekuensi Tinja Mencit Selama 3 Jam/30 Menit

\begin{tabular}{|c|c|c|c|c|c|c|}
\hline \multirow{3}{*}{$\begin{array}{c}\text { Replikasi } \\
\text { mencit }\end{array}$} & \multirow{3}{*}{$\begin{array}{c}\begin{array}{c}\text { Aquadest } \\
(-)\end{array} \\
\text { (Klp1) }\end{array}$} & \multicolumn{3}{|c|}{ Infusa Akar Kecapi } & \multirow{3}{*}{$\begin{array}{c}\begin{array}{c}\text { Loperamid } \\
(+)\end{array} \\
\text { (Klp5) }\end{array}$} & \multirow{3}{*}{ Jumlah } \\
\hline & & $15 \%$ & $30 \%$ & $45 \%$ & & \\
\hline & & (Klp2) & (Klp3) & (Klp4) & & \\
\hline 1 & 6 & 7 & 4 & 3 & 3 & 31 \\
\hline 2 & 15 & 5 & 6 & 6 & 5 & 42 \\
\hline 3 & 17 & 8 & 2 & 2 & 5 & 42 \\
\hline Jumlah & 38 & 20 & 12 & 11 & 13 & 94 \\
\hline Rara-rata & 12,6 & 6,6 & 4 & 3,6 & 4,3 & - \\
\hline
\end{tabular}

Sumber Data: Primer 2019

\section{B. Pembahasan}

Uji efek anti diare rebusan Akar Bayam Duri (Amaranthus spinosus L) terhadap hewan uji mencit jantan (Mus musculus) maka di simpulkan bahwa rebusan akar bayam duri (Amaranthus spinosus L) pada konsentrasi $10 \% \mathrm{~b} / \mathrm{v}, 30 \% \mathrm{~b} / \mathrm{v}$, $40 \% \mathrm{~b} / \mathrm{v}$ memberikan efek anti diare pada hewan uji mencit dan Akar Bayam Duri (Amaranthus spinosus L) dengan konsentrasi $40 \%$ b/v 
memberikan efek anti diare yang paling tinggi dan tidak berbeda nyata dengan suspensi loperamid.

Pemberian rebusan Akar Bayam Duri (amaranthus spinosus) terhadap mencit dengan konsentrasi $10 \% \mathrm{~b} / \mathrm{v}, 30 \% \mathrm{~b} / \mathrm{v}$, tidak berbeda nyata $(1<2,70)$ konsentrasi $10 \% \mathrm{~b} / \mathrm{v}, 40 \% \mathrm{~b} / \mathrm{v}$, tidak berbeda nyata $(2,<2,70)$, konsentrasi $30 \%$ b/v, $40 \%$ $\mathrm{b} / \mathrm{v}$, dan suspensi loperamid tidak berbeda nyata. Hal tersebut menunjukan bahwa ke empat perlakuan setelah pemberian rebusan akar bayam duri dan suspensi loperamid sebagai kontrol positif memberikan efek anti diare yang bermakna di bandingkan dengan air suling sebagai kontrol negatif.

Dari dua perlakuan masing-masing 15 ekor mencit dibagi dalam lima kelompok dan setiap kelompok terdiri dari tiga mencit.kelompok I mencit diberikan kontrol negatif yaitu Aquadest, Kelompok II, III, dan IV mencit diberikan infusa akar kecapi masing-masing dengan konsentrasi $15 \% \mathrm{~b} / \mathrm{v}, 30 \% \mathrm{~b} / \mathrm{v}$, dan $45 \% \mathrm{~b} / \mathrm{v}$. dan kelompok $\mathrm{V}$ mencit diberi kontrol positif, yaitu suspensi Loperamid.

Sebelum perlakuan mencit dipuasakan selama 3-4 jam. Hal ini dimaksudkan untuk menghindari adanya interaksi antara zat aktif dengan makanan yang terdapat dilambung serta memudahkan pemberian secara oral karena dapat dipuasakan terlebih dahulu kemungkinan makanan akan dimuntahkan atau dikeluarkan melalui mulut saat perlakuan (Kliegman, 2010).

\section{PENUTUP}

\section{A. Kesimpulan}

Pengaruh dua tumbuhan dengan konsentrasi berbeda dapat memberikan efek antidiare pada hewan uji mencit jantan (Mus musculus). Infusa rebusan akar bayam duri (Amaranthus spinosus L) pada konsentrasi $10 \% \mathrm{~b} / \mathrm{v}, 30 \% \mathrm{~b} / \mathrm{v}, 40 \% \mathrm{~b} / \mathrm{v}$ dan infusa akar kecapi (Sandoricum koetjape) pada konsentrasi $15 \% \mathrm{~b} / \mathrm{v}, 30 \% \mathrm{~b} / \mathrm{v}$ dan $45 \% \mathrm{~b} / \mathrm{v}$.

Pengaruh infusa pada konsentrasi tinggi yaitu 45\% akar kecapi (Sandoricum koetjape) dan 40\% rebusan akar bayam duri (Amaranthus spinosus $\mathrm{L}$ ). Pada memberikan efek antidiare pada hewan uji mencit jantan (Mus musculus), dan lebih tinggi di banding dengan loperamid sebagai kontrol Positif.

\section{B. Saran}

1. Kepada pembaca dan masyarakat agar dapat memanfaatkan tumbuhan yang ada disekitar pekarangan kita sebagai obat pertolongan pertama ketika mengalami diare.

2. Diharapkan penelitian ini dapat dilanjutkan untuk pengujian Bahan Tambahan Pangan yang dapat memberi manfaat dengan menggunakan teknologi dan metode yang lebih spesifik guna.

\section{DAFTAR PUSTAKA}

Priyanto. 2009. Farmakologi Terapi Dan Terminologi Medis : Jakarta

Bahasoan, Y dan Maria, G. 2007. Kapita Selekta Kedokteran. Edisi keenam jilid 2: Jakarta

Ernawati, Santoso. Fakultas Farmasi, Khasiat Buah dan Sayur: Jakarta

Harborne, K. 2009. Farmakognosi II. Fakultas Farmasi Politeknik Kesehatan: Jakarta

Jazanul, A. 2009. Farmakologi Dan Terapi: Yogyakarta

Juffrie, A. 2010. Sinopsis Farmakologi. Edisi keempat. PT. UBM Medica Asia: Jakarta

Kliegman, R. 2010. MIMS Indonesia Petunjuk Konsultasi. Edisi 12 : Jakarta Selatan

Malole, M.B.M dan Pramono, C.S.U. 1989. Penggunaan Hewan- Hewan Percobaan di Laboratorium. Direktorat Pendidikan Tinggi Pusat Antar Universitas Bioteknologi IPB : Bogor

Rahmawati Elfi dan widyatama Rendra, 2008. Analisis Kebutuhan Program Pencegahan Diare. Yogjakarta

Sari, L.O.R. 2006. Pemanfaatan Obat Tradisional Dengan Pertimbangan Manfaat Dan Kesehatan. Majalah Ilmu Kefarmasian : Jakarta 